\title{
PENGARUH MOTIVASI BELAJAR DAN PEMAHAMAN KONSEPTUAL TERHADAP HASIL BELAJAR MATEMATIKA PADA MATERI KELILING DAN LUAS BANGUN DATAR SEDERHANA SISWA SDN PAGERWOJO SIDOARJO
}

\author{
Weni Tria Anugrah Putri ${ }^{1}$, Siti Maghfiroh Amin ${ }^{2}$, MV. Roesminingsih ${ }^{3}$ \\ Program Studi Pendidikan Dasar, Program Pascasarjana, Universitas Negeri Surabaya \\ email:wtriaanugrahputri@gmail.com
}

\begin{abstract}
Abstrak
Penelitian ini bertujuan untuk: 1) menganalisis motivasi belajar dan pemahaman konseptual berpengaruh secara bersama-sama terhadap hasil belajar matematika pada materi keliling dan luas bangun datar sederhana siswa SDN Pagerwojo Sidoarjo; 2) Menganalisis motivasi atau pemahaman konseptual, variabel yang lebih dominan dalam mempengaruhi hasil belajar matematika pada materi keliling dan luas bangun datar sederhana SDN Pagerwojo Sidoarjo. Populasi dalam penelitian ini yaitu seluruh siswa kelas III SDN Pagerwojo. Subjek dalam penelitian ini yaitu 105 siswa kelas III. Pengambilan sampel di dalam penelitian ini dilakukan secara acak. Pengumpulan data dalam penelitian ini yaitu berupa angket motivasi belajar, tes pemahaman konseptual dan dokumentasi hasil belajar siswa pada materi keliling dan luas bangun datar sederhana. Teknik analisis data yang digunakan yaitu analisis linear berganda dan dan Uji-t dua variabel bebas. Hasil penelitian ini menunjukkan bahwa variabel motivasi belajar dan pemahaman konseptual berpengaruh secara simultan terhadap hasil belajar matematika siswa kelas III SDN Pagerwojo. Hal ini dapat dilihat dari nilai $\mathbf{F}_{\text {hitung }}$ sebesar 84,825 dengan tingkat signifikansi kurang dari $\alpha=0,05$ yaitu 0,000 . Selain itu, hasil penelitian juga menunjukkan bahwa variabel pemahaman konseptual adalah variabel yang paling dominan dalam mempengaruhi hasil belajar matematika pada siswa kelas III SDN Pagerwojo Sidoarjo. Hal ini dapat dilihat dari $\mathbf{t}_{\text {hitung }}$ variabel pemahaman konseptual sebesar 6,918 yang lebih besar dari $\mathbf{t}_{\text {hitung }}$ variabel motivasi belajar yang sebesar 1,343. Berdasarkan hasil penelitian, dapat disimpulkan bahwa motivasi belajar dan pemahaman konseptual berpengaruh secara simultan terhadap hasil belajar matematika pada materi keliling dan luas bangun datar sederhana siswa SDN Pagerwojo Sidoarjo. Dalam hal ini, pemahaman konseptual adalah variabel yang memberikan pengaruh paling dominan terhadap hasil belajar matematika pada materi keliling dan luas bangun datar sederhana siswa SDN Pagerwojo Sidoarjo.
\end{abstract}

\begin{abstract}
:
The purposes of this research was to analyze learning motivation and conceptual understanding gave the effect simultaneously to the result of learning mathematic in material of perimeters and areas at students of State Elementary School Pagerwojo Sidoarjo; 2) to analyze learning motivation or conceptual understanding that can be the most dominant variable for effecting the result of learning mathematic on material of perimeters and areas of the simple two dimensional geometric shapes at students of State Elementary School Pagerwojo Sidoarjo.The population in this research was all of three graders of State Elementary School Pagerwojo Sidoarjo. The subjects in this research was 105 three graders. The collecting of sample in this research was randomly.The collecting data in this research was learning motivation questionnaire, conceptual understanding test and document of the result of learning on material of perimeters and areas of the simple two dimensional geometric shapes. The technique for analyzing data was double linear analysis and t-test for two independent variables. The result of this research showed that the variables of learning motivation and conceptual understanding was effected simultaneously to the result of learning mathematic of State Elementary School Pagerwojo Sidoarjo's three graders. This result was from the score of $\boldsymbol{F}_{\text {statistics }} 24,825$ with significant base score under $\alpha=0,05$ that is 0,000 . The result of this research also showed that conceptual understanding variable was the most dominant one for effecting the results of learning mathematic at three graders of State Elementary School Pagerwojo Sidoarjo. It can be showed by $\boldsymbol{t}_{\text {statistic }}$ of understanding of conceptual variable 6,918, this total was upper from $\boldsymbol{t}_{\text {statistic }}$ of motivation to learn variable 1,343. Based on research results, the conclusion was learning motivation and conceptual understanding was effecting simultaneously to the results of learning mathematic on material of perimeters and areas of the simple two dimensional geometric shapes at students of State Elementary School Pagerwojo Sidoarjo. In this research, conceptual understanding was be the most dominant variable that effecting the results of learning mathematic on material of perimeters and areas of the simple two dimensional geometric shapes of State Elementary School Pagerwojo Sidoarjo's students.
\end{abstract}


Keywords: Learning Motivation, Conceptual Understanding, The Result of Learning, Perimeters and Areas of The Simple Two Dimensional Geometric Shapes.

\section{PENDAHULUAN}

Di Indonesia, matematika menjadi mata pelajaran yang harus diikuti oleh semua siswa di semua jenjang pendidikan. Perbedaannya terletak pada materi yang harus ditempuh, semakin tinggi jenjang pendidikan maka semakin kompleks materi matematikanya. Dengan demikian di jenjang pendidikan sekolah dasar, materi yang dipelajari bersifat sederhana. Salah satunya yaitu pengenalan terhadap konsep keliling dan luas bangun datar sederhana. Hal ini sejalan dengan pendapat Syahrir (2010: 8) yang menyatakan bahwa matematika berfungsi untuk mengembangkan kemampuan menghitung, mengukur, menurunkan dan menggunakan rumus matematika yang diperlukan dalam kehidupan sehari-hari melalui materi pengukuran, geometri, aritmatika sosial, peluang dan statistik. Konsep tersebut masuk dalam ranah pengukuran dan geometri. Di dalam jenjang pendidikan terlihat pula keterkaitan antara satu materi pembelajaran dengan materi pembelajaran yang lain di dalam matematika. Keterkaitan ini menyebabkan siswa memiliki kewajiban untuk memahami materi matematika dari awal.

Seorang siswa yang cenderung kurang mampu memahami konsep sifat-sifat bangun datar, maka siswa tersebut juga akan mengalami kesulitan dalam memahami konsep luas dan keliling bangun datar sederhana. Meskipun dalam mengerjakan soal-soal yang berhubungan dengan luas dan keliling bangun datar telah disediakan rumus yang praktis, namun hasil belajar seorang siswa akan lebih memuaskan apabila siswa tersebut memahami bagaimana mencari luas ataupun keliling suatu bangun datar sederhana melalui suatu pembuktian. Siswa yang kurang memahami konsep luas dan keliling bangun datar sederhana akan mengalami kesulitan pada pembelajaran luas dan keliling bangun ruang. Luas balok bisa didapatkan dengan luas alas dikalikan tinggi balok tersebut. Jika siswa tersebut cenderung kesulitan dalam mengenali nama-nama tiap sisi-sisi bangun tersebut, maka siswa tersebut akan menemui kesuliran bagaimana mendapatkan luas alas balok tersebut. Hal tersebut akan semakin terlihat rumit apabila siswa tersebut ternyata kurang mampu menghafal atau memahami operasi hitung yang berfungsi sebagai aplikasi dari rumus keliling atau luas bangun datar. Hal ini kembali kepada awal mula mempelajari bangun datar sederhana yang dimulai dari mempelajari keliling dan luasnya. Materi ini pun bisa menjadi sebagian akhir dari kesulitan yang terakomodasi jika siswa tidak memahami materi sebelumnya.

Materi pembelajaran tentang bangun datar merupakan materi yang berada pada hampir setiap jenjang pendidikan matematika, hanya saja yang membedakan adalah kekompleksan setiap materi. Materi keliling dan luas bangun datar salah satunya diajarkan pada kelas III sekolah dasar. Materi ini terletak pada kelas III semester kedua dengan standar kompetensi geometri dan pengukuran kelima yang berbunyi menghitung keliling, luas persegi dan persegi panjang, serta penggunaannya dalam pemecahan masalah. Lebih rinci kembali, dituliskan ke dalam dua kompetensi dasar yaitu yang berbunyi menghitung keliling persegi dan persegi panjang serta menghitung luas persegi dan persegi panjang (Depdiknas, 2006: 423). Di dalam penelitian ini, keliling dan luas bangun datar sederhana yang dibahas yaitu persegi dan persegi panjang.

Seorang siswa yang memahami materi keliling dan luas bangun datar sederhana akan mampu melakukan menjawab berbagai tipe pertanyaan yang berhubungan dengan materi tersebut. Ketika soal pertama yaitu tentang mencari sebuah keliling dengan persegi panjang yang diketahui panjang kedua sisinya, maka siswa yang memahami konsep keliling persegi panjang akan dengan mudah menghitungnya. Cara yang ditunjukkan bisa dengan menggunakan cara informal melalui menghitung panjangnya sekeliling persegi panjang ukuran dari suatu titik kembali ke titik itu lagi ataupun dengan cara formal melalui penggunaan rumus praktis. Bahkan jika siswa diberikan soal dengan proses kognitif lebih tinggi tingkatannya dari soal tersebut, maka akan cenderung mampu untuk mengerjakannya. 
Berdasarkan wawancara dengan guru di SDN Pagerwojo Sidoarjo, menyatakan bahwa meskipun sudah dijelaskan mengenai konsep tersebut, terdapat beberapa siswa yang masih juga merasa bingung. Terdapat beberapa siswa yang belum mampu menjawab soal-soal yang berhubungan dengan materi tersebut. Beberapa siswa merasa bingung dengan soal-soal yang berada di atas soal dalam ranah mengingat. Jika siswa diminta untuk mencontohkan sebuah persegi panjang yang memiliki ukuran yang berbeda dengan yang dicontohkan oleh guru, maka siswa tersebut masih merasa kesulitan. Atau pemberian soal tentang menggambar persegi dan persegi panjang dengan luas yang sama, hal itupun menjadikan sebagian siswa merasa kesulitan. Belum lagi bagi siswa yang memang masih merasa kesulitan menghafal atau memahami bagaimana pemerolehan keliling dan luas bangun datar tersebut. Hal ini akan menjadi pengakumulasi kesulitan di materi ini.

Dan ada beberapa hal lagi yang mungkin tidak teridentifikasi secara akurat tentang kelemahan siswa dalam materi ini. Hal tersebut disebabkan terkadang beberapa hal yang ditanyakan guru kepada seorang siswa dan siswa tersebut tidak mampu menjawab, siswa lain ikut membantu menjawabnya tanpa guru meminta. Dalam sekali waktu siswa yang tidak mampu menjawab pertanyaan tersebut mampu menjawab, namun hanya sekedar mampu menjawab tanpa memahami darimana jawaban tersebut berasal. Hal tersebut berlanjut dengan kesulitan yang ditemukan kembali oleh siswa di dalam materi selanjutnya yang berhubungan dengan materi ini. Ketika guru memberikan beberapa soal tentang materi ini, bagi siswa yang benar-benar mampu memahami akan mudah menjawab, namun bagi siswa yang sebaliknya belum memahami akan mencari jawaban yang berasal dari mencontoh teman. Hal inilah yang terkadang akan tetap mendapatkan skor saat penilaian, walaupuan sebenarnya siswa kurang memahami hasil akhir tersebut

Dimyati dan Mudjiono (2006) menyatakan bahwa hasil belajar merupakan hasil yang dicapai dalam bentuk angka-angka atau skor setelah diberikan tes hasil belajar pada setiap akhir pembelajaran. Angka yang dimaksud adalah sebagai sebuah simbol yang ditunjukkan kepada siswa agar siswa mampu memberikan kesimpulan terhadap tingkat kemampuannya memahami materi yang diajarkan. Walaupun demikian, hasil belajar matematika yang diperoleh siswa di dalam materi ini terkadang tidak sesuai dengan tingkat pemahaman konseptual yang dimiliki oleh siswa. Misalnya, siswa yang memahami konsep mampu mengerjakan soal yang diberikan oleh guru, maka dapat dipastikan bahwa hasil belajar siswa dalam materi keliling dan luas bangun datar sderhana ini adalah baik. Sebaliknya, siswa yang kurang memahami ini apabila diberikan maka hasil belajar yang diperoleh siswa kurang baik.

Hasil belajar merupakan tingkat kemajuan siswa dalam mencapai tujuan pembelajaran yang dikehendaki (Nurkancana dan Sumartana, 1986: 24). Seringnya ditemui suatu pemahaman konseptualtualtualtualtual yang kurang pada diri siswa namun hasil belajarnya baik. Hal yang menyebabkan hasil belajar siswa tidak sesuai dengan tingkat pemahamannya terhadap konsep yang sedang dipelajari adalah tujuan pembelajaran yang dikehendaki tidak berada pada dimensi tingkat proses kognitif memahami. Jika tujuan pembelajaran yang ingin dicapai hanya pada tingkat dimensi proses kognitif mengingat, maka hal ini akan menyebabkan hasil belajar siswa akan baik, namun pemahaman konseptual kurang. Berbeda lagi dengan jika tujuan pembelajaran dalam materi tersebut lebih dari dimensi proses kognitif mengingat bahkan sampai pada tingkat yang paling tinggi yaitu mencipta atau merencanakan, maka hal tersebut bisa dipastikan bahwa siswa mendapatkan hasil belajar yang baik dan tingkat pemahaman konseptualtualtualtual yang baik. Dengan demikian dapat dikatakan bahwa pemahaman konseptualtualtualtual belum tentu searah kemajuannya dengan hasil belajar, namun bisa dikatakan searah apabila tujuan pembelajaran berada pada dimensi proses kognitif memahami atau di atasnya.

Berdasarkan gambaran permasalahan di atas maka, pemahaman konseptualtualtualtual merupakan salah satu hal yang dapat memengaruhi hasil belajar siswa menjadi tidak maksimal. Hal ini didukung oleh pendapat Winkel \& Mukhtar (dalam Sudaryono, 2012: 44) yang menyatakan bahwa pemahaman merupakan kemampuan seseorang untuk mengerti atau memahami sesuatu hal setelah hal tersebut 
diketahui atau diingat yang mencakup kemampuan menangkap makna dari bahan yang dipelajari. Siswa yang benar-benar memahami konsep keliling dan luas bangun datar sederhana akan mampu menjawab berbagai soal dengan tipe yang sama ataupun dengan tipe berbeda yang diberikan oleh guru dengan benar. Hal inilah yang akan mempengaruhi hasil belajar siswa tersebut terhadap

Di dalam melakukan pembelajaran, setiap siswa pada umumnya menemukan kebingungan dan kesulitan dalam memahami materi. Hal yang terkadang menjadi momok pembelajaran matematika, yaitu setelah siswa memelajari materi yang ada dalam matematika. Di tengah perjalanan menemui kesulitan dan siswa tersebut malas untuk mempelajarinya kembali, maka selamanya siswa tersebut akan menganggap matematika itu sangat sulit. Atau karena sebab lain, siswa merasa malu untuk mengakui bahwa sedang mengalami kesulitan dalam materi tersebut. Rasa malu ini akhirnya berkembang menjadi rasa malas untuk mempelajari materi selanjutnya. Hal ini sejalan dengan yang dituliskan Adiputri (2014) yang menyatakan bahwa berdasarkan survey yang dikeluarkan oleh PISA (Programme for International Student Assessmenti), Indonesia berada pada peringkat paling bawah di antara 65 negara dalam kemampuan matematika, membaca dan sains. Keberadaan Indonesia di tingkat tersebut disebabkan karena pemahaman konseptualtualtualtual yang cenderung kurang baik, dan siswa tidak memiliki kegigihan untuk tetap mempelajarinya. Berbeda dengan siswa yang memiliki kegigihan dalam belajar, meskipun siswa tersebut menemui kendala, namun dengan semangatnya akan menjadikan siswa tersebut mampu memahami materi yang dipelajarinya.

Azwar (2000: 143) menyatakan bahwa motivasi mampu mendorong seseorang agar mau berbuat secara optimal dalam melaksanakan sesuatu yang telah direncakan untuk mencapai tujuan yang telah ditetapkan. Kesulitan yang dialami oleh siswa dalam pembelajaran matematika pada dasarnya akan menemui kemudahan apabila siswa termotivasi dalam mengikuti pembelajaran. Siswa yang tidak memiliki motivasi akan tetap mengikuti pembelajaran, namun akan semakin menumpuk kesulitan dalam memahami, karena materi yang ada dalam matematika bersifat berkesinambungan. Satu materi berkaitan dengan materi selanjutnya.

Berdasarkan pemikiran tersebut, maka penulis merasa tertarik untuk melakukan penelitian yang berkaitan dengan materi keliling dan luas bangun datar sederhana. Judul penelitian ini yaitu: Pengaruh Motivasi Belajar dan Pemahaman konseptualtualtualtual terhadap Hasil Belajar Matematika pada Materi Keliling dan Luas Bangun Datar Sederhana Siswa SDN Pagerwojo Sidoarjo.

\section{METODE}

Pendekatan penelitian yang digunakan dalam penelitian ini adalah pendekatan kuantitatif. Jenis penelitian yang digunakan yaitu penelitian expostfacto.Total sampel dalam penelitian ini adalah 105. Berikut ini merupakan bagan yang menggambarkan keterkaitan variabel-variabel dalam paradigma penelitian ini:

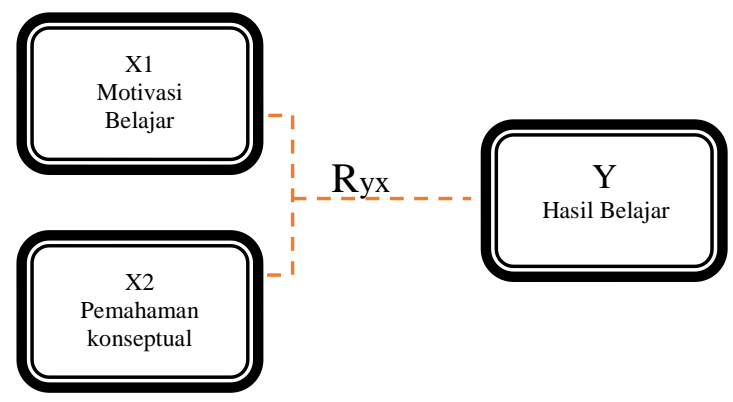

Gambar 1: Paradigma Penelitian

Penelitian ini dilaksanakan di SDN Pagerwojo Sidoarjo. Sekolah ini beralamat di Jalan Pagerwojo no. 1 Sidoarjo. Penelitian ini mulai dilaksanakan pada bulan Januari 2015. Pada penelitian ini dilaksanakan uji validitas, uji reliabilitas, uji beda dan uji taraf kesukaran terhadap tes pemahaman konseptual. Pada angket motivasi belajar tidak dilakukan pengujian statistik karena angket yang digunakan dalam penelitian ini adalah angket yang telah dikembangkan oleh peneliti sebelumnya. Pada nilai hasil belajar siswa kelas III SDN Pagerwojo Sidoarjo diperoleh dari dokumen guru kelas dan butir soal yang diberikan oleh guru dianalisis dengan butir soal yang terdapat dalam tes pemahaman konseptual.

\section{HASIL DAN PEMBAHASAN}


Uji validitas ini dilakukan hanya pada tes pemahaman konseptual. Item pertanyaan yang ada dalam tes pemahaman konseptual adalah sebanyak 32. Uji validitas pada pada variabel ini dilakukan sebanyak dua kali. Hal ini disebabkan oleh adanya empat buah item yang gugur (tidak valid), yaitu pada item nomor $6,8,14$, dan 15 . Item tersebut dikatakan tidak valid karena besarnya $r_{\text {hitung }}$ lebih kecil dari $r_{\text {tabel }}$. Pada penelitian ini besarnyanya $r$ adalah 0,374 dengan derajat kebebasan sebesar $\mathrm{dk}=\mathrm{n}-2=30-2=28$ dan $\alpha=0,05$.

Seperti halnya uji validitas, maka pada uji reliabilitas ini hanya dilakukan pada tes pemahaman konseptual. Untuk mempersingkat waktu perhitungan, maka digunakan aplikasi SPSS 15 for Windows Evaluation Version. Tes ini dikatakan reliabel apabila memiliki nilai Alpha Cronbach lebih besar dari $r_{\text {tabel }}$ yang sebesar 0,374 . Berdasarkan hasil perhitungan tersebut, maka tes pemahaman konseptual ini dikatakan reliabel dengan nilai Alpha Cronbach's sebesar 0,976 . Hasil perhitungan ini dapat dilihat pada Lampiran 20.

\section{PENUTUP}

\section{Simpulan}

Berdasarkan hasil analisis regresi linear berganda pada variabel motivasi belajar, pemahaman konseptual dan hasil belajar menunjukkan bahwa terdapat pengaruh motivasi belajar dan pemahaman konseptual secara bersama-sama terhadap hasil belajar matematika pada materi keliling dan luas bangun datar sederhana siswa SDN Pagerwojo Sidoarjo. Hal ini dapat dilihat dari nilai $F_{\text {hitung }}$ sebesar 84,825 dengan tingkat signifikansi kurang dari $\alpha=0,05$ yaitu 0,000 . Dengan demikian dapat disimpulkan bahwa motivasi belajar dan pemahaman konseptual berpengaruh secara bersama-sama terhadap hasil belajar siswa, sehingga hipotesis 1 ini dapat diterima.

Pemahaman konseptual merupakan variabel yang paling berpengaruh terhadap hasil belajar matematika pada materi keliling dan luas bangun datar sederhana siswa SDN Pagerwojo Sidoarjo. Hal ini dapat dilihat dari $t_{h i t u n g}$ variabel pemahaman konseptual sebesar 6,918 yang lebih besar dari $t_{\text {hitung }}$ variabel motivasi belajar yang sebesar 1,343. Dengan demikian dapat disimpulkan bahwa pemahaman konseptual merupakan variabel yang paling berpengaruh terhadap hasil belajar, sehingga hipotesis 2 ini dapat diterima.

\section{Saran}

Berdasarkan hasil penelitian, maka disarankan: Bagi guru, pembelajaran dengan materi keliling dan luas bangun datar sederhana tidak hanya menyangkut kedua hal tersebut saja, tetapi juga menyangkut bentuk bangun datar. Hal ini berrarti bahwa sebelum melangkah pada materi keliling dan luas bangun datar sederhana, hendaknya guru mengajarkan cara memberikan nama pada bangun datar tersebut.

Bagi sekolah, pembelajaran dengan materi keliling dan luas ini memerlukan alat tulis yang lebih banyak daripada materi yang lain, yaitu dengan adanya tambahan penggaris, baik digunakan untuk menggambar bangun datar di buku tulis maupun di papan tulis. Dengan demikian untuk mempersingkat waktu pembelajaran, sebaiknua pihak sekolah mempersiapkan penggaris kepada seluruh siswa yang disimpan di dalam lemari kelas. Sehingga tidak ada peristiwa penggaris yang tidak terbawa ke sekolah.

Bagi peneliti lain, apabila hendak menggunakan tes hasil belajar seperti halnya yang digunakan peneliti, maka sebaiknya memberikan animasi di dalam tes yang diberikan agar siswa merasa tertarik untuk mengerjakannya. Selain itu sebelum melaksanakan penelitian, persiapkan alat-alat penelitian secara lengkap. Sedangkan bagi peneliti lain yang hendak menggunakan angket sebagai instrumen penelitian maka disarankan untuk memilih kalimat yang sesuai dengan perkembangan bahasa responden.

\section{DAFTAR PUSTAKA}

Syahrir. (2010). Metodologi Pembelajaran Matematika. Yogyakarta: Naufan Pustaka.

Depdiknas. (2006). Kurikulum Tingkat Satuan Pendidikan. Jakarta: Depdiknas.

Sudaryono. (2012). Dasar-dasa Evaluasi Pembelajaran.Yogyakarta: Graha Ilmu.

Adiputri, Novi Christiastuti. (2014). RI Terendah di PISA, WNA: Indonesian Kids Don't 
Know How Stupid They Are, (Online), (m.detik.com/news/read/2014/02/08/15312 4/2491125/10/), diakses 12 Februari 2015.

Nurkancana dan Sumartana. (1986). Evaluasi Pendidikan. Surabaya: Usaha Nasional.

Azwar, Saifuddin. (2000). Sikap Manusia. Yogyakarta: Pustaka Pelajar. 